\author{
René Levy, Felix Bühlmann \& Eric Widmer
}

\title{
Dual and single career couples in Switzerland: Exploring partners' trajectories
}

\author{
Doppel- und Einzelkarrierepaare in der Schweiz: eine Studie der \\ Berufsverläufe zusammenlebender Partner
}

\begin{abstract}
:
Based on retrospective data from a sample of 602 women and 621 men living in couples surveyed in Switzerland in early 1999, professional trajectories of partners are compared using the optimal matching technique in order to distinguish typical sequence models. We identify dual-career couples and distinguish them from other couples with dual- or single-employment, showing that dual-career couples proper are a rather rare phenomenon, and that mobility trajectories continue to be strongly gendered: male trajectories respond to a predominantly occupational logic, whereas female trajectories are structured by both an occupational and a familial logic. A multinomial regression analysis allows to identify some of the factors conditioning couples' trajectory constellations.
\end{abstract}

Key words: occupational mobility, family, gender, work-family balance, life course

\begin{abstract}
Zusammenfassung:
Anhand retrospektiver Daten einer Stichprobe von Anfang 1999 befragten Paaren (602 Frauen und 621 Männern) vergleichen wir die Berufsverläufe zusammenlebender Partner und ermitteln typische Verlaufsmodelle. Mittels der Optimal-Matching-Technik identifizieren wir Doppelkarrierepaare und unterscheiden sie von anderen doppel- oder einfachverdienenden Paaren. Doppelkarrierepaare erweisen sich dabei als relativ selten. Außerdem sind Mobilitätsverläufe nach wie vor stark geschlechtsspezifisch: männliche Verläufe folgen einer reinen Beschäftigungslogik, weibliche Verläufe unterliegen zugleich einer Beschäftigungs- und einer Familienlogik. Eine multinomiale Regressionsanalyse erlaubt, einige der Bedingungsfaktoren für das Vorliegen der verschiedenen Paarkonstellationen zu identifizieren.
\end{abstract}

Schlagworte: berufliche Mobilität, Familie, Geschlechterverhältnisse (Gender), work-family balance, Lebenslauf, linked lives

The level of scientific interest in dual career couples seems relatively high and stable, even if it may have passed its peak. This attention reflects the growing importance of the phenomenon itself on both the private and the public level, as the longterm rising female employment rates in most Western countries indicate (for European countries see Rubery et al. 1999, Maruani 2003). More specifically, the proportion of couples with a male breadwinner decreases whereas double-earner couples increase their share (according to Jacobs \& Gerson, 2004, 51\% of all American 
couples had a unique, male breadwinner in 1970 , but only $26 \%$ in 2000 ; in Switzerland, the corresponding figures are $75 \%$ and $37 \%$ ). The equally growing literature on issues of work-life balance shows that this development engenders problems of many sorts, and that dual-career couples might be less than the hoped-for positive model of modernised, egalitarian family organisation that brings high and equal satisfaction to all its members. The topic takes us right into the heart of gender relations, not only with respect to "horizontal" differentiation, but also with respect to inequality. It focuses our attention on the intersection of the two institutional realms of occupation and the family since it concerns both of them at a time, i.e., occupational mobility, its antecedents and mechanisms as well as family engagement with its opportunities and constraints.

In this perspective, looking at the conditions that facilitate the emergence or stabilisation of dual-career families may be at least as interesting as looking at their consequences (for the partners' marital satisfaction, for children's socialisation, etc.). Our contribution tries exactly this: after stating our definition of the concept, we identify it empirically by using a novel methodology allowing to take directly into account individuals' biographical trajectories, to classify them into empirically determined trajectory types, and to treat them as a dependent variable.

\section{Definitions and theory}

Before engaging in any theoretical reasoning, some definitional clarification is necessary. Despite the presence of the notion of "dual career" in the research literature since more than 35 years, the terms used are still varied, the definitions not always well explicated and even less consensual. Let us take up some basic aspects.

On the basis of what criteria should we define double-career couples, by partners' mutual career ambition, by their effective upward mobility, or by other criteria of "success"? We follow the proposition of Hiller \& Dyehouse (1987) and other authors to reserve the phrase "dual-career" to couples in which both partners are engaged in upwardly mobile occupational paths. To what extent upward mobility is accompanied or even explained by career ambitions is an empirical question, not a definitional one. We therefore consider ambitions as a phenomenon different from careers - i.e., movements in the social structure's hierarchical dimension - which makes them an inadequate indicator for our purpose. The same holds true for other possible criteria sometimes used in the literature, such as education. Moreover, men's and women's career (or, for that matter, also non-career) ambitions, i.e., their attitudes and biographical projections, may ask for mobilising a rather different theoretical context than factual trajectories; this is another reason to separate their conceptual definitions. A further particularity should be mentioned in this context: with respect to European countries, the operational identification of career with occupational status is not warranted. High educational degrees may neither be the only nor sufficient conditions to lead to upward occupational mobility, even though they are particularly favourable for it to happen. 
It is equally important to distinguish between dual-earner and dual-career couples, dual-career being one subvariant of dual-earner couples. Other typical dualearner situations exist: couples with non-mobile, downwardly-mobile, irregularlymobile (sometimes up, sometimes down) or differently-mobile partners (the most frequent being probably the combination of "she stable, he upwardly mobile"). It may be possible that we find no empirical difference between dual-career couples and dual-earner couples without upward mobility as to certain features or consequences of their common life, but this is one of the interesting empirical questions and should not be presupposed by way of definition. It is especially interesting to see if there are associations between the male and female partners' occupational trajectories, since we know that in many countries, these trajectories are different in terms of shape, frequency, continuity vs. interruption, etc. Indeed, in her study of inter-country variations, Maruani $(1993,2003)$ has identified three global types of employment trajectories for women in European countries: steady employment, resembling the male model, rapid and definitive exit from the labour market, most likely at marriage, and temporary exit, most likely at birth of the first child, followed by later re-entry. Beyond the studies exclusively focused on dual-career couples, the question of the relative frequency and social location of these couples is also important; it may turn out that they are rather exceptional, and this simple fact merits to be studied as well as more intricate features.

Should we rather talk about dual-career couples or dual-career families, or are these de facto synonyms ? This distinction is highly important; dual-career families are composed not only by adult partners, but include one or more children. ${ }^{1}$ The literature shows that in many occidental countries, couple equality with respect to occupational engagement is much more wide-spread in the pre-child phase of family life than in the subsequent phases. However, there are important international variations, partly correlated with the countries' welfare-state regimes and their impact on family- and other biographical choices (Korpi 2000, Blossfeld \& Drobnič 2001, Levy et al. 2006, Nollert 2006). This gives particular importance to the couple-vs.family distinction; we therefore include all couples in our analyses and use the presence of children as a potentially explanatory variable.

Explaining dual-career couples usually comes down to explain women's occupational participation, especially with respect to the factors responsible for its being steady, reduced, or interrupted; in comparison, explaining men's employment is rarely at stake. One argument in favour of this practice might be that in practically all studies of occupational trajectories, variation is wide among women whereas male trajectories appear as constants instead of variables. In Switzerland, empirical studies show that a large majority of male occupational trajectories are steady between first job entry and retirement, except for rather rare "biographical accidents" such as unemployment or health impairments, and contain only few episodes with

1 We exclude monoparental families since by definition they leave no room for a dualcareer situation in the usual sense of the term. This is not to pretend that it would not be interesting to study the dynamics of both partners of former couples, or of informal and may be not cohabiting couples in a similar perspective. Unfortunately, these situations can not be identified with our data. 
part-time employment. This differs strongly from women's trajectories, many of which are characterised by interruptions or reduction to less than full-time employment, especially during phases of active mothering (Widmer, Levy et al. 2003; Levy, Gauthier \& Widmer 2006). Nevertheless, male trajectories should not by principle be excluded from analysis as their very steadiness merits explanation, too (Eichler 1988).

Two theoretical perspectives on female labour force participation have been widely debated: the more classical economic theory of partners' rational choice (Becker 1981) and Hakim's (2000) preference theory, offering an individualistic and culturalist explanation for the differential participation in the labour market of women and men living in couples. Neither of these theories has provided satisfying results in recent studies (see especially the thorough account of Blossfeld \& Drobnič, 2001; Drobnič \& Blossfeld 2001; Schulz \& Blossfeld, 2006). ${ }^{2}$ One plausible reason for this unsatisfactory situation may be that these theories, explicitly or implicitly, consider women's lesser labour-force participation as "their problem", i.e., as explainable by factors concerning individual women, a lopsided perspective on two accounts. First, why should it be more relevant to explain women's lesser labour-force participation rather than men's constant and stronger one? Second, why should we exclude by design the possibility of interdependences between the partners living together? Women's lesser or men's stronger occupational integration may as well be conditioned on their partner's configuration as on their own factors; the logic that influences how the two partners adapt to changing situations, especially to the birth of a child, may also be proper to the couple and not to one of its members.

For this reason we rather refer to perspectives that allow to include the couple as a collective actor with an internal structure characterised by varying degrees of inequality and forms of labour division. One such perspective is that of gendered life courses organised by sex-specific master statuses as proposed by Krüger \& Levy (2001) that we shall expose when interpreting our results. Since our analysis has an exploratory outlook, we prefer to include a range of potentially relevant aspects to strict hypothesis testing on the basis of a highly elaborated theoretical frame of reference. We therefore limit ourselves at this point to mentioning a series of interesting dimensions without a lengthy discussion of their underlying mechanisms, conditions, and effects.

Beyond purely economic factors such as differential utility functions, human capital optimization, partners' earning capacities, and their relation to familial labour division, we consider power and its legitimacy to be an interesting dimension, be it in the perspective of the resource-theoretical model as handed down since Blood \& Wolfe (1960) or in that of patriarchy or male privilege and its acceptance,

2 Let us cite just one typical phrase in Drobnič \& Blossfeld 2001 (p. 372) who were longtime defenders of economist approaches: "From the point of view of the economic theory of the family, the resource-bargaining model, and the marital dependency model, the division of labour in couples therefore remains a puzzle". One of the main components of that puzzle is that these models suppose gender neutrality of actors' behaviours which is squarely contrary to empirical results. 
defence, or challenge, as formulated, e.g., by Connell (1987) or Walby (1990). A supplementary element in a more complete vision of the dynamics implied in the relation between extra- and intra-couple factors is the prestige differential between housework and employed work. Its importance derives not only from the fact that housework is unpaid, but also from other aspects, intrinsic as well as extrinsic. Compared with most paid work, the quality and results of housework cannot easily be appreciated "objectively". Moreover, its "appropriation" takes place in a private space and relationship, not in public or on a market. It has a repetitive, routine character and little satisfaction potential, and is therefore less attractive than other activities (see for early treatments Eichler 1976, Held 1978). This configuration characterises family work more generally; many elements of care work can be described by similar features. An important and difficult problem, rarely attacked systematically in empirical research, is the question of the sources of marital power (see already Safilios-Rothschild 1970) and their measurement and weighting, especially sources other than earning (like network strength, relational and other social competencies, etc.). A companion aspect is the accessibility of alternatives to the existing couple relationship, which may also be an important base of power differentials. The power-and-privilege dimension may be seen as close to the doing-gender aspect since traditional male identity includes domination and breadwinning whereas traditional female identity includes acceptance of being status-dependent and dominated (Bielby \& Bielby 1989, 1992). Another group of interesting factors is not individual or couple-bound, but contextual and institutional: the availability of childcare and of family-compatible workplaces. They depend mainly on the institutional outfit of society on the local, regional or national level.

Against this backdrop, our contribution is first of all exploratory. With a view to the widespread discourse about recent change in women's situation within and without the family, and also in couple organisation, we wish to clarify the question conceptually and empirically. Can we content ourselves by distinguishing between dual-career couples and others or should we use a more differentiated classification? How can we locate dual-career couples in the global landscape of couples' occupational participation in Switzerland? What are the conditions presiding over couples' strategies? Our central criterion for distinguishing non-earners, non-career earners, and career earners will be the individuals' occupational trajectories or careers (Spilerman, 1977) as defined in an intragenerational perspective. This restrictive operational definition allows us to include social origin in the analysis of trajectories rather than "burying" it in the definition of the trajectories themselves.

\section{Data and methods}

Sample: The data stem from a postal retrospective follow-up to a representative telephone survey of 1534 couples living together (married or not) in Switzerland conducted in winter 1997/98 (main study: Widmer, Kellerhals et al. 2003), addressed to the couples who agreed to be contacted again ( $96 \%$ of the initial sample). About half of the initial couple members returned their questionnaires in due time 
(717 women, 703 men). The questionnaire was deliberately limited in scope and concerned only a few factual aspects of training, employment, and cohabitation (Widmer, Levy et al. 2003). On the basis of the information concerning the whole sample, the respondents of the retrospective questionnaire are a representative subsample, showing no significant deviation from the initial sample. The analysis of male and female trajectories is based on the responses of the 602 women and 621 men aged 30 or more (for reasons of trajectory identifiability) and presenting a sufficient proportion of non-missing information. The $\mathrm{N}$ at hand for couple analyses is lower $(\mathrm{N}=505)$ because in some couples, only one of the partners answered.

The information about the independent variables has been mainly collected in the initial survey and concerns aspects of social status and family composition.

For social origin we rely on father's occupational position as the main status variable. It has the double advantage to designate the social origin of the respondents' trajectories and to be analytically independent of the trajectories themselves. ${ }^{3}$ We also consider national origin as a secondary status marker that may influence mobility trajectories which we call civic status because it is legally defined and constitutes a social hierarchisation on the basis of the extent of civic rights granted (here dichotomised into Swiss vs. alien). ${ }^{4}$ Furthermore, we use two indicators of family composition, the number of children ${ }^{5}$ and the father's age at the birth of the first child, considering that the temporal placement of childbirth may be a component of career planning. Finally, we include male respondents' age at the beginning of the (actual) partnership relation (with or without marriage, and irrespective of cohabitation). ${ }^{6}$

Our main dependent variables are sequence types of male and female occupational trajectories defined by help of the eight kinds of biographical situation or "states" the available year-by-year information allows us to distinguish: worker/ employee, middle manager, higher manager, self-employed, non-employed homeworker, full-time education or training, retired, other (unpaid leave, travel, benevolent worker, unemployment, military service, accident, sickness, etc.). ${ }^{7}$ In the case of information overlap, especially between employment and family work, (full-time)

3 It is not possible to add the respondents' education because by its duration it is part of the dependent variables.

4 Several empirical indications attest, e.g., the diminished value of foreigners' education with respect to the attainable job positions in Switzerland (Levy et al., 1997).

5 Unfortunately, the low number of couples without children (12\% of 505 , i.e., 62$)$ does not allow to distinguish no children and one child. Analyses with less restrictions - and hence more cases - indicate that the strongest difference exists between these very two categories that have to be collapsed here.

6 Taking the male rather than the female partner's information for the two age variables is a purely arbitrary decision. Both age variables, especially if recoded into three classes as we use them, are so highly correlated between the partners (gamma $=.84$ for age at first childbirth and .75 for age at partnership inception) that they cannot be used together in a regression analysis.

7 The hierarchical differentiation tapped by the occupational subset of these categories is rather crude, especially for lower ranks; moreover, we cannot distinguish between fulltime and part-time employment. 
employment is given priority. Taking into account various employment situations along with non-employment situations is important to compare male and female trajectories; it would make little sense to artificially restrict our analysis to employed respondents, especially as employment interruptions are a typical ingredient of female trajectories and may have an important incidence on their occupational mobility.

On the basis of this grid, individual trajectories are described as sequences of such states (one state for each year of life between 20 and maximally 64). The sample contains all ages, which implies that the number of individuals diminishes with increasing age; this explains the limitation of the analysis to the age bracket just mentioned. The individual trajectories are compared to each other by optimal matching analysis which establishes their resemblance or dissemblance in terms of a distance measure, thus creating a matrix of distances between individual trajectories (see Appendix 1 for a brief explanation of optimal matching analysis). In order to discover to what extent there exist consistent patterns of trajectories in terms of typical sequences of these states, we apply hierarchical cluster analysis (Ward) to these distance measures. The final dependent variable describes the combination of the couples' male and female trajectory types and will be analysed by multinomial regression.

Auxiliary variables: In order to better grasp the meaning of the trajectory types, we use a series of additional variables as descriptors that neither enter into the definition of the trajectories nor will be used in the subsequent analyses. These are respondent's social origin as represented by father's occupational position (8 categories) and mother's employment (employed vs. not employed) at respondent's age 15, their intergenerational educational mobility (trichotomised into upward, stable, and downward, based on a five-fold information of hierarchical educational levels), $h i$ erarchical level of occupation trained for (8 categories), hierarchical level actually occupied (8 categories), actual personal income (7 classes), and rate of employment (not employed, low part-time, i.e. under $50 \%$, high part-time, and full time). The three measures of occupational position (father's, respondent's vocational training, actual) are the official Swiss "socio-professional categories" (Joye \& Schuler 1995). These categories - except one - constitute a hierarchical order; the exception is that of smaller self-employed which are very heterogeneous with respect to social position. ${ }^{8}$ Finally, we include actual age, dichotomised into younger or older than 50 . These auxiliary variables are displayed in appendix table A1 for men and A2 for women; their features will enter into the description of the trajectory types (next section). In order to simplify the reading of these tables, the variables are dichotomised, showing the percentages of specific categories for each trajectory type (in the case of the occupational hierarchy, "high" positions are those higher than qualified, but non-managerial jobs).

8 Obviously, occupational training and even more so actual occupation are a part of individuals' trajectories as grouped into our types. But they highlight specific biographical time points rather than development. Their inclusion in the enriched description of the types is therefore not redundant. 


\section{Double-career couples and others: identifying trajectory types}

Hence, we describe the respondents' trajectories in terms of the above-mentioned eight states on a yearly basis by optimal matching analysis, done separately for men and women and followed by cluster analysis. The decision about the number of clusters was taken on the basis of the stopping rules evaluated by Milligan and Cooper (1985). These rules help decide how many "real" clusters are present in the data. The stopping rule for a statistically optimal cluster solution can be defined as a local peak of the pseudo- $F$ (high ratio between inter- and intra cluster variance), associated with a low value of pseudo $t^{2}$ that increases at the next fusion, and a marked drop of the overall R-squared ${ }^{9}$. The selected solutions of four clusters or trajectory types for men and five for women correspond to these conditions.

\section{Male trajectories}

Let us start with the description of the male trajectories, using graphs that show for each cluster the year-by-year histograms of the distribution of the eight states we can distinguish. ${ }^{10}$ In order to enrich the description of the resulting trajectory types, we include results from appendix tables A1 and A2.

An important proportion of male trajectories (about a fourth) are grouped in a cluster we call Slow Career (fig. 1) because they are slowly and modestly ascending. The graph shows that the training period rapidly diminishes its proportion until age 26 , then phases out around mid-life, with very few exceptions. More importantly, job entry happens for half of these men on the lowest hierarchical level we can identify, for another half on mostly middle levels, and gives rapidly way to middle (very rarely higher) management positions or to self-employment. So the upward mobility of this trajectory type is largely restricted to the passage from rank and file to middle management positions or to self-employment. Non-employment states are insignificant, except retirement among the elders.

Looking at table A1 for a "thicker" description, we can see that the profile of social origin of this trajectory type is relatively modest, fathers were rarely selfemployed, the rate of upward educational mobility is close to the mean; occupational training took place mostly in not very high-ranking sectors. With respect to most indicators in this table, this type does not stand out as particularly low or high. It may be compared to the social image of modest upward mobility gained by "working one's way up", based on acquired experience rather than on formalised qualification.

9 Ratio between interclass variance and total variance.

$10 \mathrm{It}$ is important to note that these age profiles are not based on the theoretical assumption that age is an important determinant of the trajectories, but only on their practical utility for synthesising longitudinal information. Their main limitation is that they cannot directly show the individual trajectories that define the trajectory types. 
Fig. 1, Slow Career $(\mathrm{n}=161,27 \%)$

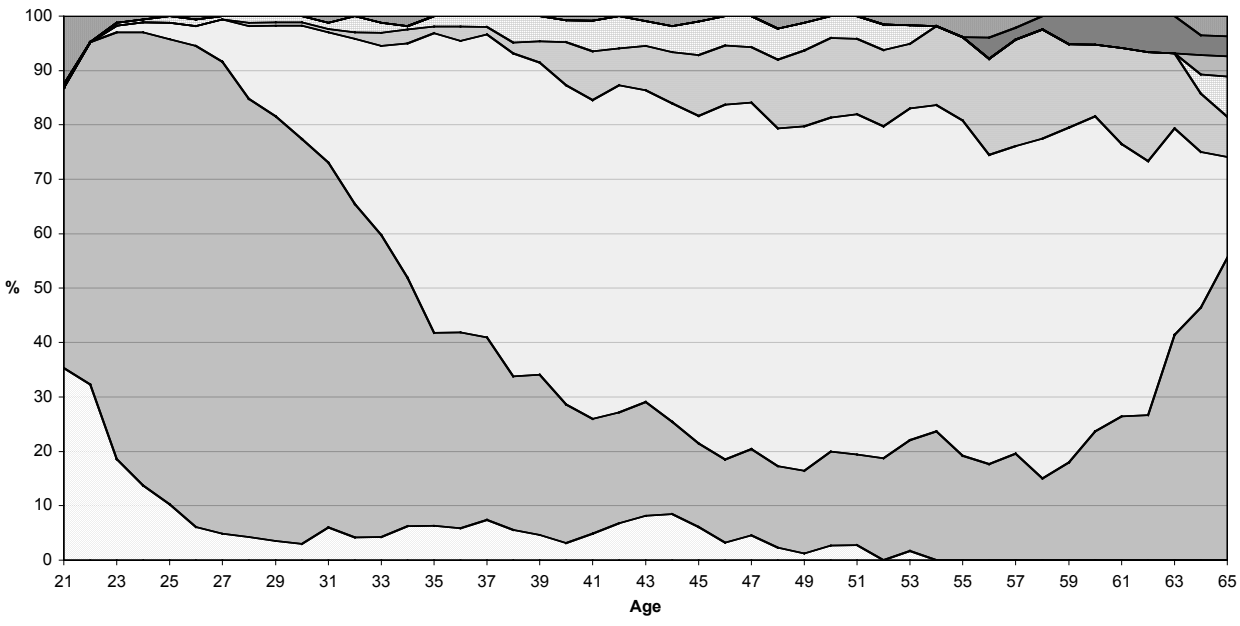

$\square$ ¿ducation $\square$ worker/ employee $\square$ middle management $\square$ higher management $\square$ self-employed $\square$ motherhood $\square$ retirement $\square$ others $\square$ missing

Fig. 2, High Career $(\mathrm{n}=124,21 \%)$

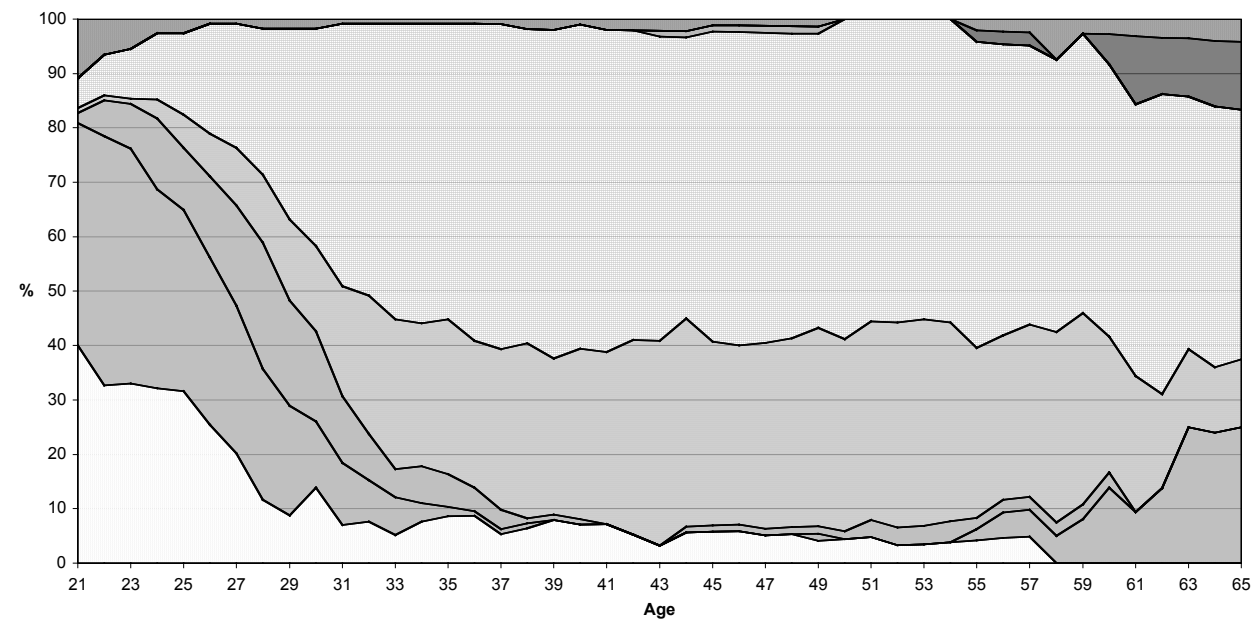

Đeducation $\square$ worker/employee $\square$ middle management $\square$ higher management $\square$ self-employed $\square$ motherhood $\square$ retirement $\square$ others $\square$ missing

In comparison, the second type, High Career (fig. 2) assembles a somewhat smaller proportion of male trajectories (one fifth). They are characterised by a longer phase of education, a more rapid transition to positions in middle and higher management, and a hint to a more direct relevance for job positioning of the higher levels of edu- 
cation attained. Upward mobility is clearly faster than in the previous type and sets in almost immediately after job entry; self-employment becomes relatively important in this trajectory type and remains so all along.

According to table A1, this trajectory type is most strongly linked to selfemployed fathers, it shows also the highest rate of self-employed respondents and of high incomes and the "highest" age distribution (although nonsignificant). It seems to combine two different mechanisms of attaining privileged positions, the "meritocratic" one based on formal qualification and the "patrimonial" one of inheriting material or cultural means of production.

Fig. 3, Nonmobile Workers (n=189, 32\%)

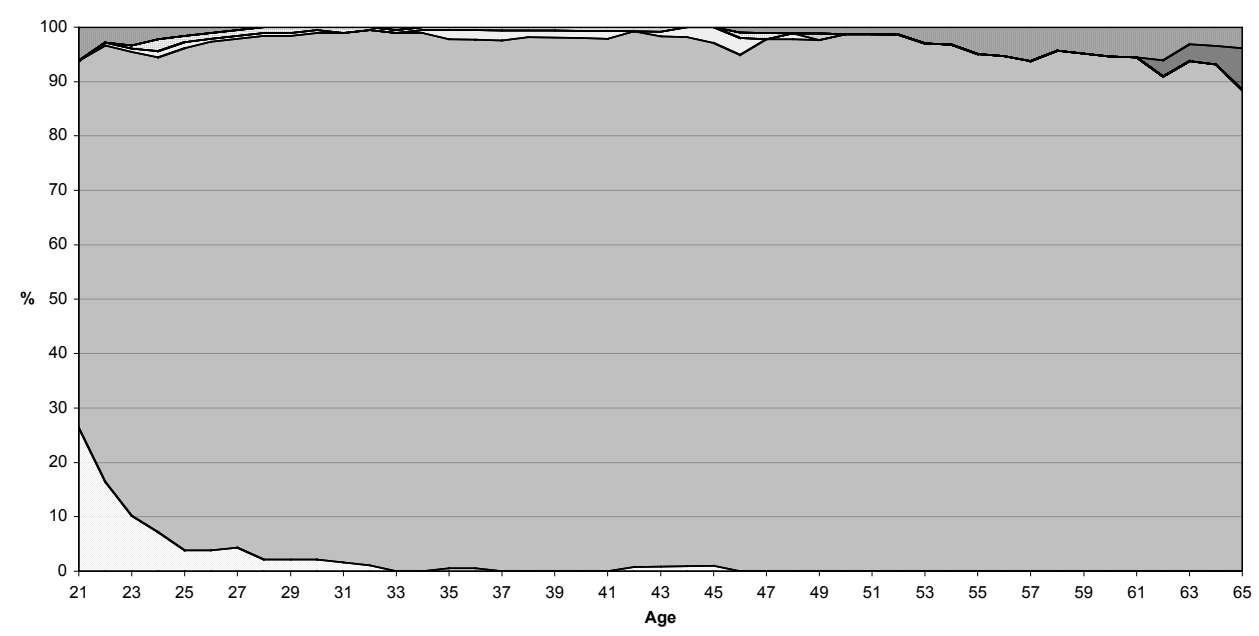

$\square$ education $\square$ worker/employee $\square$ middle management $\square$ higher management $\square$ self-employed $\square$ motherhood $\square$ retirement $\square$ others $\square$ missing

The third type, Nonmobile Workers (fig. 3), is numerically the most important. It conveys practically no sign of upward mobility, job entry occurs rather quickly after initial education which is not followed by further education later on in life (but can be supposed to include vocational training). Thus, a third of adult Swiss men seems to be "scotched" onto the bottom level of the job hierarchy once and forever.

Table A1 confirms that their trajectories remain close to the bottom of social stratification according to our status criteria: their social origin is very modest, their educational mobility is close to the mean, they have the lowest proportion of training for high-ranking occupations and actually occupy such positions rarely, including self-employment which is a hierarchically heterogeneous category; their income is particularly low. Their age distribution is more concentrated in lower-than-themean categories than the other trajectory types, but age differences are not significant. This type of trajectory seems to describe the life course of the working classes, i.e., manual and nonmanual employees with no or little formal qualification and hence little prospects of promotion. Seen in a macrosociological perspective, it rep- 
resents the other face of the reproduction of social inequalities: whereas high qualification is the most central asset to upward mobility, low qualification is the most important impediment to it (for the centrality of education in the Swiss mobility regime, see Levy et al., 1997).

Fig. 4, Middle Management ( $\mathrm{n}=119,20 \%)$

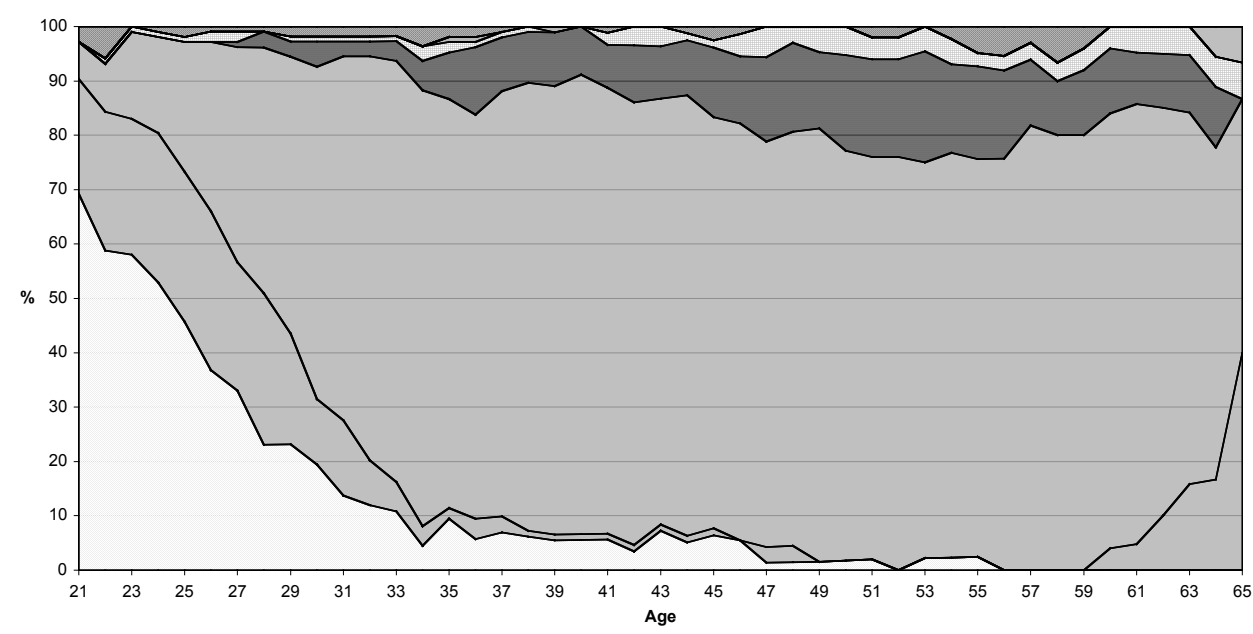

口education $\square$ worker/ employee $\square$ middle management $\square$ higher management $\square$ self-employed $\square$ motherhood $\square$ retirement $\square$ others $\square$ missing

We call the fourth and last trajectory type Middle Management (fig. 4) because its members attain this level either directly after initial education or more or less quickly later on (probably on the basis of prolonged training, as indicated by the continuing, although diminishing presence of education), but still early in their careers. They remain there until retirement without climbing higher up.

We learn from table A1 that their trajectories start out from higher social origins than the preceding types, but rarely from conditions of parental self-employment, and they occur rarely after upward educational mobility (which is probably due to an already high educational level of their fathers). Their mothers were more often employed than for the other types. Their age distribution fairly corresponds to the overall means. This kind of trajectory occurs most often in relation with training for relatively high-ranking occupations, which are also most often effectively attained. ${ }^{11}$ They concern principally men who gain high incomes as salaried managers rather than being self-employed. This "stable high" trajectory seems more purely tributary

11 It is interesting to note that for all trajectory types except Nonmobile Worker, the rate of actual occupancy of high occupational positions is clearly higher than the rate of training for such positions. This reflects the general upward mobility due to the economic expansion Switzerland has enjoyed during the 25-30 years after World War II. 
of higher levels of education, corresponding to the meritocratic perspective, than High Career where we found also hints at the alternative mechanism of capital inheritance.

Overall, then, we find two patterns of upward mobility and two patterns of hierarchical stability, the mobile patterns representing $48 \%$ of all male trajectories, the stable patterns $52 \%$. All four trajectory types are based on full-time employment and can therefore be considered employment-centred. No specific type of downward mobility emerges from the data. ${ }^{12}$ Intergenerational reproduction of social position shows up quite strongly, in accordance with other findings from Switzerland and other countries, with a major importance of educational positioning (a more meritocratic track, but backed up by cultural inheritance as we know from studies of intergenerational mobility, see Levy et al., 1997) and a minor one of capital inheritance (a more patrimonial track).

Mother's employment varies little between the types with the exception of a high value among Middle Management trajectories, probably due to the general mechanism of educational homogamy and the well-known relationship between women's higher education and their maintaining employment throughout the family life cycle.

By and large, the male trajectory types confirm the selectivity of upward mobility, the existence of different mechanisms of mobility (meritocratic vs. patrimonial), and a rather high overall level of intergenerational reproduction (as postulated by Bourdieu, 1970). To come back to our initial vocabulary, we observe two careerearner types, and two non-career earner types among men, but no non-earner trajectory type.

\section{Female trajectories}

What about the female trajectories? Some of the five types resemble closely to types obtained for men, others not at all. Fig. 5 shows a first type which we call, here also, Slow Career.

Its temporal profile shows a prolonged importance of education, job entry at bottom, and signs of - rather modest - upward mobility, mainly into middle management or self-employment but hardly to higher management. We also see a modest presence of housewives, i.e., exclusive family work - a category absent from the male trajectories. Middle Management position as well as self-employment disappear towards retirement age, but the small $\mathrm{N}$ in this category makes it too hazardous to interpret the graph for higher ages.

Slow careers start out from intermediate or higher social origins, including selfemployed fathers (table A2), have a comparatively high occupational training that can be supposed to "help" them attain middle to higher occupational levels, including self-employment, but does not prevent them from gaining middle to lower incomes. These women tend to be younger than those in other trajectory types. We

12 A downward movement before retirement seems to be included in the three trajectory types other than Nonmobile Worker, but it shows up only for the highest years of age where the $\mathrm{N}$ are too small to warrant interpretation. 
can see here a hint at a lower "conversion rate" of formal qualification into occupational position for women, one of the more insidious components of sex discrimination in the working of social stratification.

Fig. 5, Slow Career (n=61, 11\%)

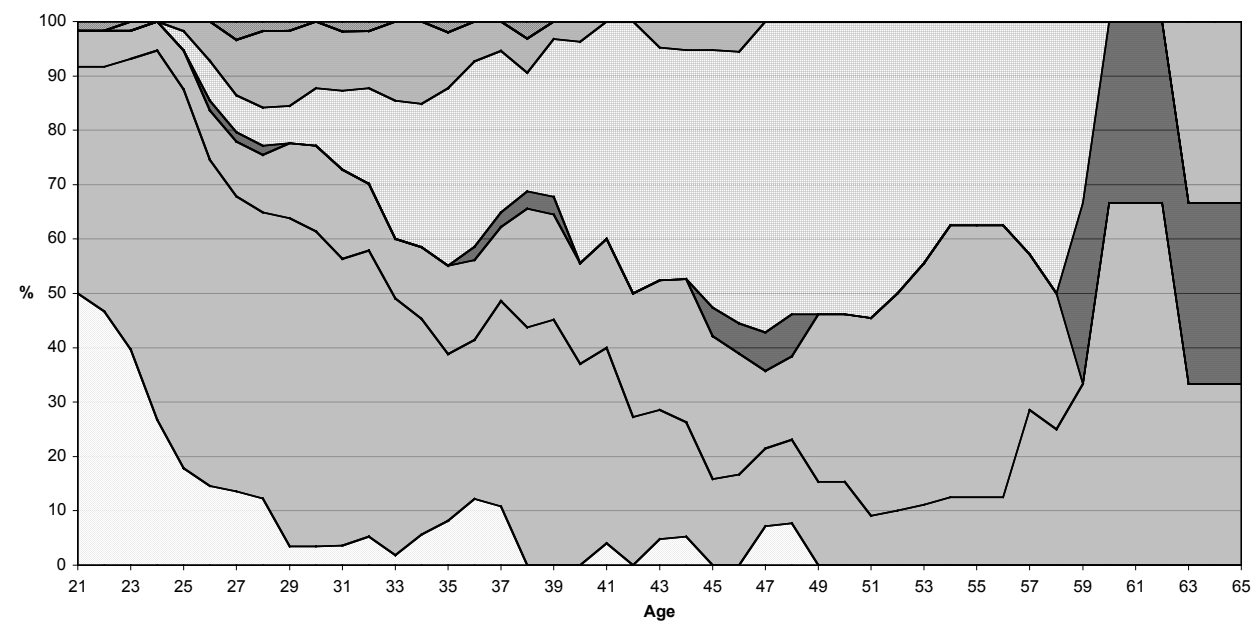

口education $\square$ worker/ employee $\square$ middle management $\square$ higher management $\square$ self-employed $\square$ motherhood $\square$ retirement $\square$ others $\square$ missing

The profile of the High Career type (fig. 6) is very different from the previous one. Education diminishes with age but remains important all along, there are very few job entries at bottom level, more on the level of middle management, and some directly on that of higher management or as self-employed. We refrain from interpreting the tendencies after midlife because of the dwindling $\mathrm{N}$ with age in this particularly small category. There is a strong indication of upward mobility in this profile; nevertheless, there is some presence of family obligations in the form of probably short - spells of "housewifery" that disappear, however, at mid-life.

Table A2 shows that High Career women's social origins are not higher than for the previous type, but parental self-employment is particularly prominent, they have also the highest frequency of an employed mother as a role model (although not significant - the same holds for their higher rate of self-employed fathers), the highest rates of upward educational mobility and of higher occupational training, and the highest rate of high positions actually occupied..$^{13}$ Accordingly, they have also the highest rate of high incomes and an equally low rate of part-time employment as the previous type, and their age distribution is rather young (but less so than for Slow Careers). We can interpret this trajectory type in parallel with that of men, upward mobility seems to

13 Let us note that to the contrary of men, a positive difference between the rate of high actual positions compared to the rate of training for jobs in such positions is not generalised among women, but a specific characteristic of the High Career trajectory. 
be mainly due to educational assets, but also to capital inheritance, although to a smaller extent than among men - and the trajectory is clearly less frequent among women than among men ( $7 \%$ vs. $21 \%)$.

Fig. 6, High Career $(\mathrm{n}=39,7 \%)$

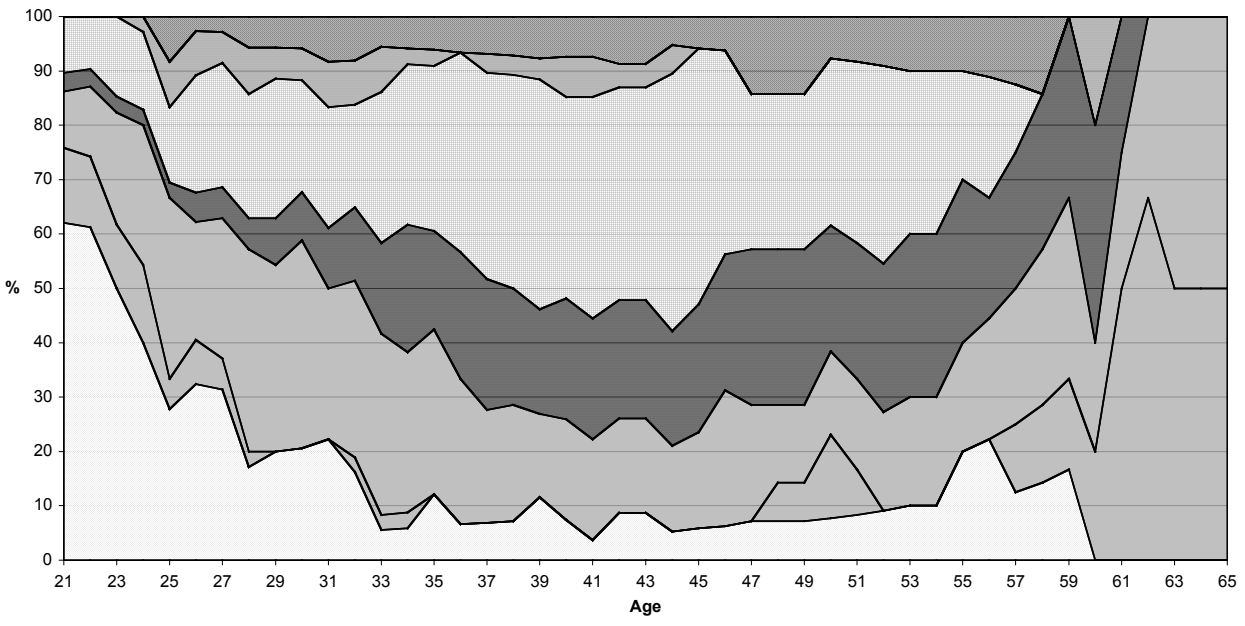

口education $\square$ worker/employee $\square$ middle management $\square$ higher management $\square$ self-employed $\square$ motherhood $\square$ retirement $\square$ others $\square$ missing

Fig. 7, Nonmobile Worker $(165,29 \%)$

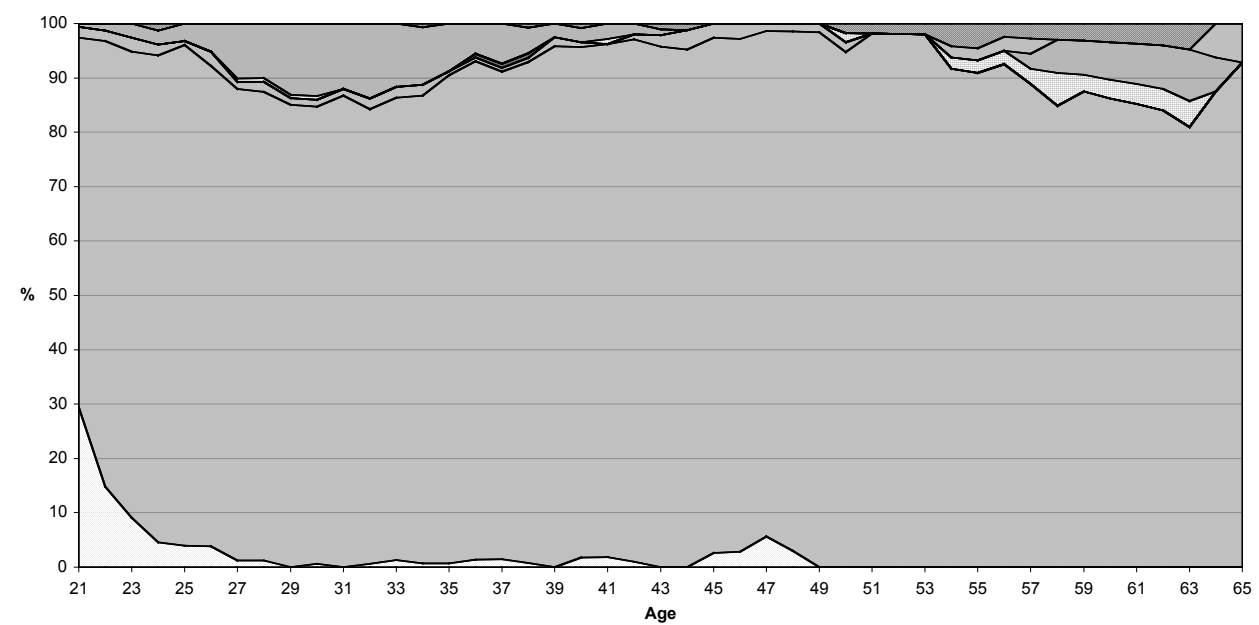

¿education $\square$ worker/employee $\square$ middle management $\square$ higher management $\square$ self-employed $\square$ motherhood $\square$ retirement $\square$ others $\square$ missing 
As among male trajectories, and with more or less the same numerical importance, we find also a female trajectory type of continuous labour-force participation on the bottom level (fig. 7), without upward mobility, but also with only a modest proportion of housewife periods.

Table A2 tells us that female Nonmobile Workers have modest social origins, especially with respect to parental self-employment, mean educational mobility, and vocational training principally for lower job levels; their actual occupations are, correspondingly, of rather low level, as are their incomes, which is partially also explained by their maximally high rate of part-time work. Their age distribution is not particularly skewed. The discrepancy between mean education and consistently low occupational position that characterises this type has also been found among men and seems due to what has been termed "educational inflation" rather than dequalification due to job interruptions. This trajectory type corresponds to the hypothesis of financial need explaining female employment maintenance.

Fig. 8, Motherhood and Return ( $\mathrm{n}=129,23 \%)$

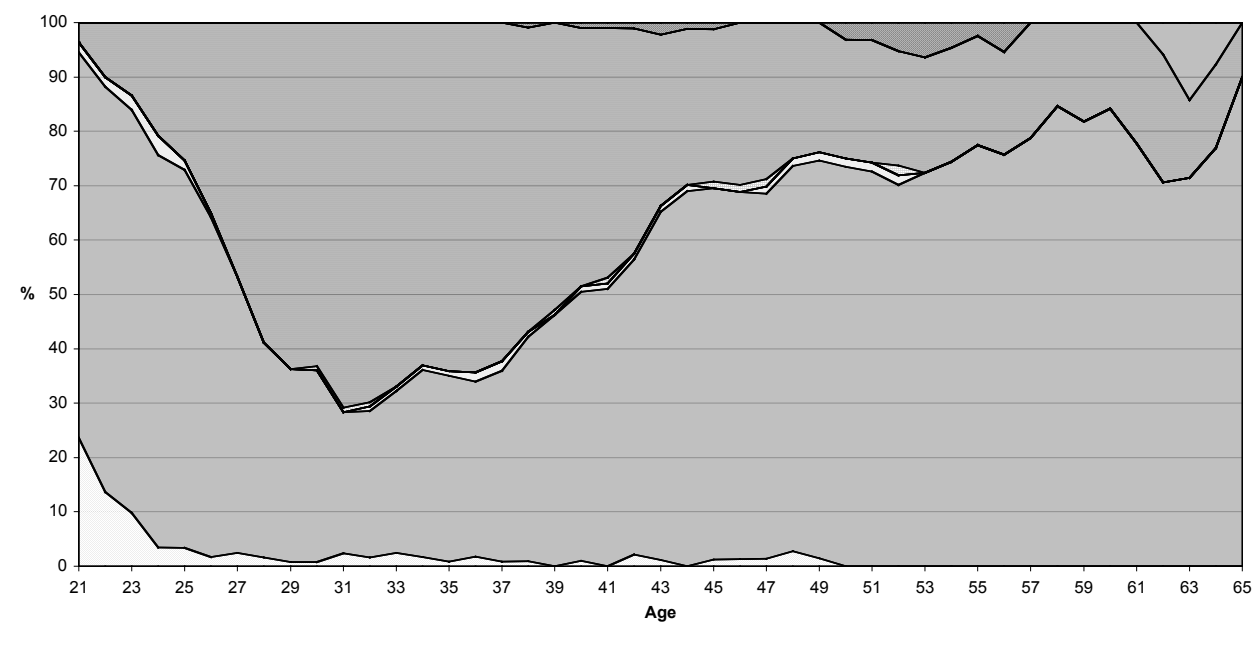

¿education $\square$ worker/ employee $\square$ middle management $\square$ higher management $\square$ self-employed $\square$ motherhood $\square$ retirement $\square$ others $\square$ missing

The fourth type (fig. 8) resembles to none of the types found among men, it is specifically female. After a rather early job entry at bottom level, these women interrupt their employment and become housewives to a degree that becomes predominant early in their thirties. After this motherhood period, and very progressively, most of them resume gainful employment.

According to table A2, this trajectory type is frequent among women with rather low social origins, with particularly rare upward educational mobility, low-level occupational training and a correspondingly low rate of higher occupational attainment, the highest rate of part-time occupation and very low income; the age distribution is the highest of the female trajectory types. These elements hint to the fact 
that the interruption of employment that defines this type is particularly concentrated on lower levels of qualification and occupational position, in accordance with the hypothesis that it is not only financial need as found for type three, but also job satisfaction, income potential and the independence potential based on it that motivate female employment maintenance throughout the life course.

The last type (fig. 9) again does not exist among men and is once more different from those we have seen up to now. After quitting education rather quickly (with a tiny exception of return to educational in later years), most of these women enter the work-force at bottom level, but leave it quickly during their twenties (a small proportion even seems never to take up a job), and most of these women remain housewives for the remainder of their lives.

Housewife trajectories are characterised, according to table A2, by rather low social origins, tend to be less upwardly mobile on education than women in other types, have rather low occupational training, but those among them who are employed at the moment of the interview nevertheless occupy mostly middle-level positions, unlike the two previous types. Their income is very low (probably owing to the fact that even women without employment indicated some income, and much less to part-time work that has its lowest proportion in this category). The age distribution is second-highest among the five female trajectory types. Here again, results tend to confirm the idea that reduction of female employment is characteristic of lower positions in the social stratification.

Fig. 9, Housewife $(\mathrm{n}=174,31 \%)$

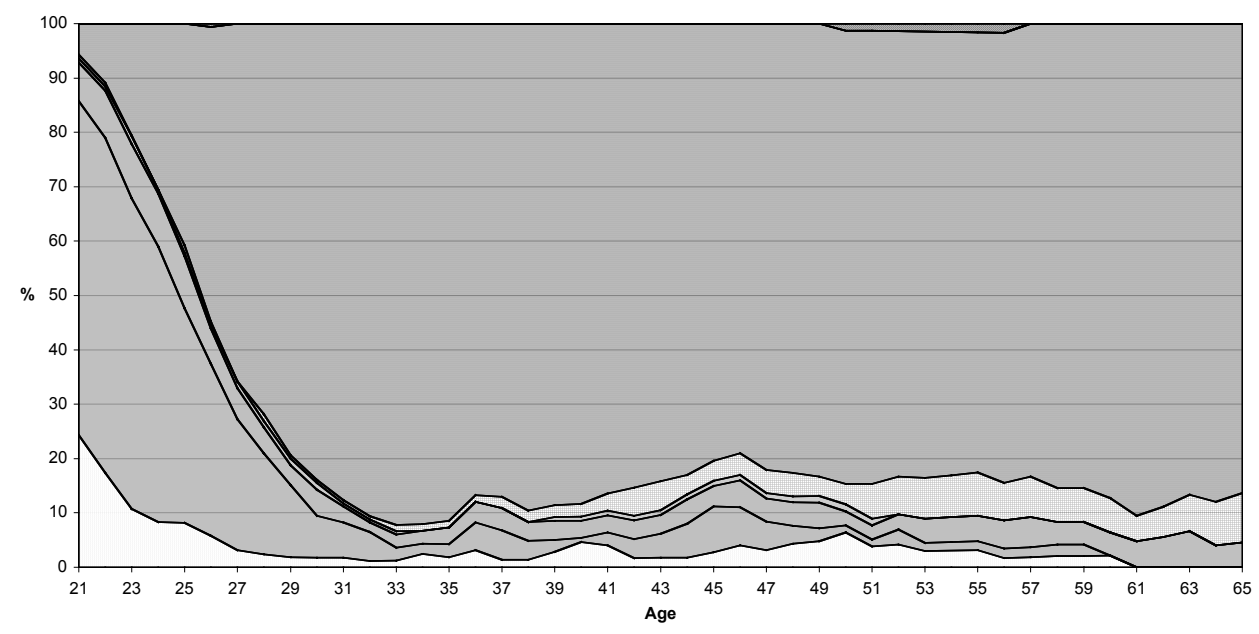

घeducation $\square$ worker/ employee $\square$ middle management $\square$ higher management $\square$ self-employed $\square$ motherhood $\square$ retirement $\square$ others $\square$ missing

The overall picture of women's trajectories is quite different from men's. Whereas all the male trajectory types are employment-centred, we find for women two strongly family-centred types, Motherhood and Return, and Housewife, adding up to 54\% of all 
individual trajectories, along with an almost equal presence of employment, divided between upwardly mobile trajectories (Slow and High Career, together 18\%), and stable, low-ranking trajectories (Nonmobile Worker with 29\%), totalling $47 \%$ employment-centred trajectories. Consistent upward mobility is much rarer among women than among men. This being said, paid work exists in practically all female trajectories, in the form of sometimes shorter, sometimes longer employment episodes. ${ }^{14}$

To sum up, the comparison of our empirically based typologies reveals a strong, if partial, sex-typing of occupational trajectories, with upward mobility considerably rarer among women than among men ( $17 \%$ vs. $49 \%)$, and family-centred trajectories inexistent among men, but very important (54\%) among women. Non-earner trajectories are a typically female phenomenon (31\%). Female pathways reflect also tougher conditions of upward mobility than male pathways: higher qualification "pays" less in terms of occupational position for women than for men, and inheritance of capital (as indicated by the intergenerational reproduction of self-employment) is rarer for daughters than for sons. The descriptive differences between male and female trajectory types are strong, in degree (inequality) and in profile (difference), principally due to the existence of two women-only trajectory types, Housewives and Motherhood and Return, and the absence of a Middle Management trajectory among women.

\section{Linked lives - linked occupational trajectories?}

Are there empirical links of co-occurrence between the trajectories of partners living together, whatever be their semantic resemblance? For a first overview, we used correspondence analysis, a statistical method designed to uncover patterns of associations among variables without assuming a causal order (Greenacre, 1993). It shows that men and women with High Careers tend to over-associate with each other. This is also the case of individuals with Slow Careers. As those couples are only a small minority (about 10\%), a large majority of couples comprising Nonmobile Worker, Middle Management, Motherhood trajectories, etc., do not show specific forms of trajectory homogamy. In order to get statistically defendable categories of couple constellations, some female and male trajectory types have to be com-

14 Contrary to men's trajectories, age differences between female types are significant, even though they do not appear very strong in absolute terms; the difference between the mean ages of the "youngest" and the "oldest" type is 7.7 years, probably less than a socially significant generational cohort. Nevertheless it is noteworthy that women who follow one of the two family-centred trajectory types tend to be somewhat older than those following one of the occupation-centred types. Rather than corresponding to a generational difference, this might be due to a stronger commitment to their role obligations as a mother that leads to prospective postponement of childbirth. Age seems to indicate in this analysis the phase in one's life course rather than cohort or generation (cfr. also the influence of age in our multinomial analysis, table 3). Other analyses attest that value change in favour of gender egalitarianism has generalised in Switzerland since the 1980s, without concomitant institutional change, however. This may explain the rather weak influence of age we find here. 
bined. ${ }^{15}$ Table 1 shows how male and female trajectory types combine and indicates how they are grouped together to form couple constellations for the subsequent analysis, based on the results of correspondence analysis.

Table 1: Association of male and female trajectory types (table percent, $\mathrm{N}=505$ )

\begin{tabular}{|c|c|c|c|c|c|c|c|}
\hline \multirow{3}{*}{$\begin{array}{l}\text { Male } \\
\text { trajectory } \\
\text { types }\end{array}$} & & \multicolumn{5}{|c|}{ Female trajectory types } & \\
\hline & & \multicolumn{2}{|c|}{ Upward career } & \multicolumn{2}{|c|}{ Stable worker } & \multirow{2}{*}{$\begin{array}{c}\begin{array}{c}\text { Exclusive } \\
\text { family } \\
\text { worker }\end{array} \\
\text { House- } \\
\text { wives }\end{array}$} & \\
\hline & & Slow caree & r High career & $\begin{array}{c}\text { Nonmobile } \\
\text { workers }\end{array}$ & $\begin{array}{l}\text { Motherhood } \\
\text { and return }\end{array}$ & & Total \\
\hline \multirow{4}{*}{$\begin{array}{l}\text { Slow career } \\
\text { High career } \\
\text { Nonmobile workers } \\
\text { Stable middle } \\
\text { management }\end{array}$} & Upward & 3.3 & 1.4 & 4.0 & 3.2 & 8.5 & 21.0 \\
\hline & career & 2.2 & 3.2 & 9.1 & 7.5 & 6.3 & 27.7 \\
\hline & Stable & 2.8 & 0.8 & 10.9 & 8.3 & 8.5 & 31.3 \\
\hline & worker & 2.0 & 1.6 & 5.1 & 4.0 & 7.3 & 20.0 \\
\hline Total & & 10.3 & 7.0 & 29.1 & 23.0 & 30.6 & 100.0 \\
\hline
\end{tabular}

The two upwardly mobile female types are combined to an Upward Career type totalling 100 cases or $17.3 \%$ of all female trajectories, the two other occupation-related female types are combined to a Stable Worker category (several analyses show that the Motherhood-and-Return trajectory contains more occupational decline or at best stability rather than upward mobility, so we can consider these women as basically employed, but without upward mobility), and Housewife becomes the third category. For men, the two upwardly mobile types are grouped together to Upward career as for women, and the two nonmobile types become a Stable Worker category (earner, no career) of which we know that it is heterogeneous with respect to hierarchical position; in the thematic context of the present article, this is acceptable.

On the basis of this "recoding", and taking up our initial terminology, we bring down the twenty partner constellations of table 1 to six as shown in table 2 .

Table 2: Couples' occupational situation $(\mathrm{N}=505)$

\begin{tabular}{lr}
\hline Dual-career & 10.1 \\
Dual-earner, female career & 7.1 \\
Dual-earner, male career & 23.8 \\
Dual-earner, no career & 28.3 \\
Male earner with career & 14.9 \\
Male earner, no career & 15.8 \\
\hline Total & 100.0 \\
\hline
\end{tabular}

Despite our recoding, Dual-career couples are still rare, they represent only one tenth of all couples. One of the categories is a-typical and also particularly rare, i.e., Dual-earner, female career. Another one, even more a-typical, would be Female earner only. It did not show up in the biographical data, probably because it corresponds more to specific and limited biographical periods than to entire trajectories. According to results from analyses of actual situations irrespective of the whole

15 Although it would be interesting to look more precisely at the double career situation proper, the very low number of cases ( 17 couples out of 505) would make results too shaky. 
trajectories, it makes up roughly $5 \%$ and concerns mainly couples with men who are non-employed for reasons of retirement, unemployment or physical impairment. The two most frequent constellations are Dual-earner, with or without male career. Together, they represent more than half of the couples (Dual earner, no career is composed by $9 \%$ of higher social status according to the male position and $19 \%$ of lower status). Male earner trajectories, with or without (male) career, i.e., the most traditional constellations, represent another third. ${ }^{16}$

\section{Double career couples and others}

On the basis of the above-defined couple constellations, we are able to examine the structural factors favouring or hindering the unfolding of double careers or other couple constellations by means of multinomial regression analysis. The dependent variable in this analysis is the typology of table 2, with Dual earner, no career as reference category. The set of independent variables includes both partners' social origin, but considers only men's civic status, men's age at the birth of the first child, and men's age at the beginning of the partnership (but not necessarily cohabitation) because of the strong homogamy with respect to these three variables. Partners' trajectory types would be interesting candidates as well, but can not be included here since their combination forms the dependent variable.

Table 3 displays some significant $(*)$ or very significant $(* *)$ ratios that focus our attention on three aspects. First, Dual career couples as well as Dual earner, female career couples are highly disfavoured by men's lower or middle class origins when compared with the reference category of Dual earner, no career couples, and particularly favoured by upper middle class or higher origins. So the rather atypical Dual earner, female career constellation appears as an upper-class phenomenon to the same extent as the more typical Dual career constellation. Second, women's social origin plays a much more modest role, even though we may see a tendency according to which women's fathers' intermediary and employee positions (i.e. lower middle-class origins) lessen the probability of all constellations with a male career, especially in the form of Male earner with career. Women of middle class origin seem mostly promised to enter into couples characterised by male hypogamy. Fi-

16 We should bear in mind that partners' occupational trajectories often start out before they form a couple, these trajectories (or the projects concerning them) may even be a direct cause for the postponement of partnership or parenthood. But then, we can also assume that when partners form a couple, they take into account their mutual occupational pathways and outlooks. What we are interested in for the present analysis is how male and female trajectories combine, and whether there are empirical indications of factors favouring or discouraging specific combinations, in order to see to what extent we can spot and begin to explain some kind of homogamy with respect not primarily to resources hold, but to trajectories. We may add that this type of "causal intertwinement" is characteristic of many interrogations about trajectories and their possible linking and should warn us against too direct causal interpretations of regression results. 
nally, the presence of two or more children strongly reinforces the Male earner, no career constellation, only tendentially also the Male earner with career constellation, and diminishes particularly the atypical Dual earner, female career situation. Put brutally, a family situation with more than one child in the household squeezes the mother out of the labour market, especially so if the first child is born early. Early couple formation (Men's age) is strongly incompatible with the Dual career situation, but non-significant for the other constellations.

These results confirm separate regression analyses of the male and female trajectory types, not shown here for lack of space, in which the partner's trajectory type was included among the independent variables. Social origin as indicated by father's occupational status, especially high status, is less decisive for male trajectories than for women's, the presence and number of children is much more decisive for female trajectories than for male ones. Another gender difference has already been mentioned: male trajectories bear signs of two distinctive logics of upward careers, a meritocratic one based on education and a patrimonial one based on inheritance of social and economic capital; the second logic is largely absent from female trajectories. Women's occupational trajectories are strongly conditioned by their mothering functions, fatherhood does not seem to influence men's trajectories. The interlinkage of partner trajectories appears to be asymmetric: not only are female trajectories somewhat more structuring for men's than men's for women's, but they reflect to various degrees and by different patterns the unilaterally female "responsibility" for family work. This is in line with the argument that female renouncement to an own occupational career (or just plain employment) is instrumental for men's upward-oriented or high-placed trajectories.

\section{Summary and discussion}

Male and female occupational trajectories have been defined by the biographical sequence of different states or life-course locations, some of them describing labourforce participation and occupational status, others describing other predominant social participations such as getting an education or doing family work. Optimal matching and clustering of individual trajectories has allowed to identify five trajectory types among women and four among men, three of which are similar between the sexes, the others being clearly sex-specific. Biographical sex-typing is revealed as persistently strong in contemporary Swiss society, probably even stronger when looked at in a life-course perspective than in a more positional or purely mobility-oriented perspective (as usually offered by statistical data). Men's trajectories are strongly influenced by their social origin, and early family formation does not seem to be career-friendly for them. These factors somehow "sort" men into more or less upward-oriented pathways, with two types of mobility motors being at work, the meritocratic one of education and the patrimonial one of capital inheritance. Women's trajectories show more radical differences than men's in that only about half of them are employment-centred, the other half family-centred; secondarily, the only mobility motor that counts for female trajectories is the meritocratic one. 
The "switch factor" that distinguishes between the two female trajectory groups is principally the presence and number of children, at least on the surface of the results. If we look at the results in a more encompassing perspective, it seems likely that this presence makes trajectories tip towards a family logic on the sole female side only in a societal gender order that is so constructed, i.e., that fixes a much higher price to pay for male than for female job reduction, by way of various forms of gender discrimination in the labour market (men get higher salaries than women for equivalent work, female education "pays less" in terms of attainment of hierarchical position and promotion than male education, the sexual segregation of occupational training and of the labour market parks a majority of women in jobs with lesser perspectives of upward mobility than men, etc.), and that moreover provides cultural justification for male privilege and female submission by discriminating social representations - which is the case of Switzerland despite generalised declarations of gender egalitarianism, including by legal provisions. Their political incorrectness makes such representations publicly indefensible, but prevents neither their being handed down between the generations by various forms of socialisation nor their informal effectiveness.

To take up again our initial questions, our results clearly indicate the necessity to distinguish couples' trajectory constellations more finely than by a simple dichotomy, since only a small minority of them can be qualified as dual-career couples and the remaining large majority, far from being homogenous, shows considerable variability, as expressed by our six-fold classification. Furthermore, the analysis has shown some strong elements of positioning with respect to both social position, inherited and own, and presence of children, and these enter into the processes of structuring couples' strategies.

Taking stock of our results, we must admit that dual career couples are of a rare kind in Swiss society, even if "career" is defined largely, including any kind of upward mobility. They stand out as an elitist phenomenon, strongly based on privileged social assets - individually achieved as well as intergenerationally inherited and are thus related to the basic mechanisms of social reproduction in inequalities, including those between men and women. Against this backdrop, they appear to be an additional mechanism enhancing rather than compensating social inequality and stratification without basically breaking gender discrimination.

In a broader perspective and with a view to further investigations, the results may be interpreted with reference to the thesis that contemporary Western societies, and more particularly some of them (such as Germany and Switzerland), have a gender regime characterised by two sex-specific master statuses (Krüger \& Levy 2001) in the sense that men are dominantly assigned to paid work, and women to family work. This gendered dissymmetry of dominant social participation is not necessarily exclusive, but implies that both men and women have their dominant and gendered field of participation. They may participate in non-dominant fields as long and to the extent that this does not interfere with their task profile in the dominant field. The present as well as earlier results (Widmer, Levy et al. 2003, Widmer et al. 2004) point strongly to the fact that the birth of the first child constitutes the very turning point for families to get reorganised according to that tradition-close model, as highlighted in our regression analysis by the differentiated and sex-specific effects of the presence and number of children. An interesting line of exploration suggested 
by this kind of results concerns the relation between different types of welfare state and a society's gender regime (see for a first attempt Levy 2006), another one consists in enlarging the set of dimensions, especially in the direction of contextual and institutional factors that tend to be equally neglected by family and stratification research. It would be interesting to include other explanatory factors in the analysis than those at hand in this study, such as the precise timing of crucial transitions of the partners, especially with respect to one another. Another limitation lies in the fact that only trajectories of people living in couples were analysed. This calls for an extension to singles' trajectories and their sex-typing - we would hypothesise that they are gendered as well, but to a lesser extent because they lack the impact of childbirth and the linked-lives effect related to being part of a couple.

\section{Bibliography}

Abbott, Andrew (1988). Transcending general linear reality. Sociological Theory, 6, pp. 169-186.

Abbott, Andrew (1992). From causes to events. Sociological Methods and Research, 20, pp. 428-455.

Abbott, Andrew \& Hrycak, Alexandra (1990). Measuring resemblance in sequence data: An optimal matching analysis of musicians' careers. American Journal of Sociology, 96(1), pp. 144-185.

Aisenbrey, Silke (2000). Optimal Matching Analyse. Anwendungen in den Sozialwissenschaften. Opladen: Leske + Budrich.

Becker, Gary S. (1981). A treatise on the family. Cambridge: Harvard University Press, Cambridge.

Bielby, William T. \& Bielby, Denise D. (1992). I will follow him: Family ties, gender-role beliefs, and reluctance to relocate for a better job. American Journal of Sociology, 97(5), pp. 1241-1267.

Bielby, William T. \& Bielby, Denise D. (1989). Family ties: Balancing commitments to work and family in dual earner households. American Sociological Review, 54(5), pp. 776-789.

Blood, Robert O. \& Wolfe, Donald H. (1960). Husbands and wives. The dynamics of married living. New York: Free Press.

Blossfeld, Hans-Peter \& Drobnič, Sonja (2001). Theoretical perspectives on couples' careers. In: Hans-Peter Blossfeld \& Sonja Drobnič (Eds), Careers of couples in contemporary society. From male breadwinner to dual-earner families. Oxford: Oxford University Press, pp. 16-50.

Bourdieu, Pierre \& Passeron, Jean-Claude (1970). La reproduction: éléments pour une théorie du système d'enseignement. Paris: Minuit (English translation: Reproduction in education, society and culture. London, Beverly Hills: Sage, 1977, 1990).

Chan, Tak Wing (1999). Optimal matching analysis, Social Research Update 1999, Issue 24.

Connell, Robert W. (1987). Gender and power: Society, the person, and sexual politics. Stanford: Stanford University Press.

Delcher, Arthur L.; Kasif, Simon; Fleischmann, Robert D.: Peterson, Jeremy; White, Owen \& L. Salzberg, Steven L. (1999). Alignment of whole genomes. Nucleic Acid Research, 27(11), pp. 2369-2376.

Drobnič, Sonia \& Blossfeld, Hans-Peter (2001). Careers of couples and trends in inequality. In: Hans-Peter Blossfeld \& Sonja Drobnič (Eds), Careers of couples in contemporary society. From male breadwinner to dual-earner families. Oxford: Oxford University Press, pp. 371-386. 
Eichler, Margrit (1988). Nonsexist research methods: A practical guide. London: Allen \& Unwin.

Eichler, Margrit (1976). The prestige of the occupation housewife. Toronto: OISE, Group for Research on Women.

Erzberger, Christian \& Prein, Gerald (1997). Optimal-Matching-Technik: Ein Analyseverfahren zur Vergleichbarkeit und Ordnung individuell differenter Lebensverläufe, ZUMANachrichten, 21(40), pp. 52-80.

Hakim, Catherine (2000). Work-lifestile choices in the $21^{\text {st }}$ Century: Preference theory. New York: Oxford University Press.

Han, Shin-Kap \& Moen, Phyllis (2001). Coupled careers: Pathways through work and marriage in the United States. In: Hans-Peter Blossfeld \& Sonja Drobnič (Eds), Careers of couples in contemporary society. From male breadwinner to dual-earner families. Oxford: Oxford University Press, pp. 201-231.

Held, Thomas (1978). Soziologie der ehelichen Machtverhältnisse. Neuwied: Luchterhand, Neuwied.

Hiller, Dana Vannoy \& Dyehouse, Janice (1987). A case for banishing "dual-career marriages" from the research literature. Journal of Marriage and the Family, 49(4), pp. 787-795.

Jacobs, Jerry A. \& Gerson, Kathleen (2004). The time divide: Work, family, and gender inequality. Cambridge: Harvard University Press.

Joye, Dominique \& Schuler, Martin (1995). La structure sociale de la Suisse. Catégories socio-professionnelles. Berne: Office fédéral de la statistique.

Korpi, Walter (2000). Faces of inequality: Gender, class, and patterns of inequalities in different types of welfare states. Social Politics, 7(2), pp. 127-191.

Krüger, Helga \& Levy, René (2001). Linking life courses, work, and the family: Theorizing a not so visible nexus between women and men. Canadian Journal of Sociology/Cahiers canadiens de sociologie, 26(2), pp. 145-166.

Levy, René (2006), Particulière, singulière ou ordinaire? La régulation suisse des parcours de vie sexués. In: Thomas Eberle \& Kurt Imhof (Eds), Sonderfall Schweiz. Zurich: Seismo, pp. 226-247.

Levy, René; Gauthier, Jacques-Antoine \& Widmer, Eric (2006). Entre contraintes institutionnelle et domestique: les parcours de vie masculins et féminins en Suisse. Canadian Journal of Sociology/Cahiers canadiens de sociologie, 31(4), pp. 461-489.

Levy, René; Joye, Dominique; Guye, Olivier \& Kaufmann, Vincent (1997). Tous égaux? De la stratification aux représentations. Zurich: Seismo.

Maruani, Margaret (1993). L'emploi dans l'Europe des Douze. Bruxelles: Commission des Communautés Européennes.

Maruani, Margaret (2003). Travail et emploi des femmes. Paris: La Découverte.

Moen, Phyllis (Ed.) (2003). It's about time. Couples and careers. New York: Cornell University Press.

Nollert, Michael (2006). Sonderfall im rheinischen Kapitalismus oder Sonderweg im liberalen Wohlfahrtskapitalismus? Zur Spezifität des Sozialstaats Schweiz. In: Thomas Eberle \& Kurt Imhof (Eds), Sonderfall Schweiz. Zurich: Seismo, pp. 153-171.

Rapoport, Rhona \& Rapoport, Robert N. (1971). Dual-career families. Baltimore: Penguin.

Rapoport, Rhona \& Rapoport, Robert N. (1969). The dual-career family: A variant pattern and social change. Human Relations, 22(1), pp. 3-30.

Rubery, Jill; Smith, Mark \& Fagan, Colette (1999). Women's employment in Europe: Trends and prospects. London: Routledge.

Safilios-Rothschild, Constantina (1970). The study of family power structure: A review 19601969. Journal of Marriage and the Family, 32(4), pp. 539-552.

Schneider, Barbara \& Waite, Linda (Eds) (2005). Being together, working apart: Dual-career families and the work-life balance. Cambridge: Cambridge University Press. 
Schulz, Florian \& Blossfeld, Hans-Peter (2006). Wie verändert sich die häusliche Arbeitsteilung im Eheverlauf? Eine Längsschnittstudie der ersten 14 Ehejahre in Westdeutschland. Kölner Zeitschrift für Soziologie und Sozialpsychologie, 58(1), pp. 23-49.

Spilerman, Seymour M. (1977). Careers, labor market structure, and socioeconomic achievement. American Journal of Sociology, 83(3), pp. 551-593.

Sussman, Marvin B. \& Steinmetz, Suzanne K. (Eds) (1987). Handbook of marriage and the family. London, New York: Plenum Press.

Sussman, Marvin B.; Steinmetz, Suzanne K. \& Peterson, Gary W. (Eds) (1999). Handbook of marriage and the family. London, New York: Plenum Press.

Walby, Sylvia (1990). Theorizing patriarchy. Oxford: Blackwell.

Widmer, Eric: Kellerhals, Jean \& Levy, René (avec la collaboration de Michèle Ernst Stähli et Raphaël Hammer) (2003). Couples contemporains - Cohésion, régulation et conflits. Une enquête sociologique. Zurich: Seismo.

Widmer, Eric; Levy, René \& Gauthier, Jacques-Antoine (2004). L'implication dans les champs domestique et professionnel selon les phases de la vie familiale. In: Erwin Zimmermann \& Robin Tillmann (Eds), Vivre en Suisse 1999-2000. Une année dans la vie des ménages et familles suisses. Berne: Peter Lang, pp. 95-108.

Widmer, Eric; Levy, René; Pollien, Alexandre; Hammer, Raphaël \& Gauthier, JacquesAntoine (2003). Entre standardisation, individualisation et sexuation: une analyse des trajectoires personnelles en Suisse, Revue suisse de sociologie/Schweizerische Zeitschrift für Soziologie, 29(1), pp. 35-67.

Submitted on/Eingereicht am: 11.01.2007

Accepted on/Angenommen am: 28.09.2007

Addressed of the authors/Anschriften der Autoren:

Prof. Dr. René Levy (corresponding author/Korrespondenzautor)

E-mail: Rene.Levy@unil.ch

Felix Bühlmann, lic.soc.

E-mail: Felix.Buhlmann@unil.ch

Prof. Dr. Eric Widmer

E-mail: Eric.Widmer@socio.unige.ch

Centre lémanique d'études de parcours et modes de vie (PAVIE)

Université de Lausanne

Centre PAVIE

Bâtiment Province

CH-1015 Lausanne 
Appendix 1: Optimal matching analysis

Since the method of optimal matching is not yet largely known in the sociological community, let us briefly present its basic analytical logic (for more detailed accounts, see Abbott 1988, 1992; Abbott \& Hrycak 1990; Erzberger \& Prein 1997; Chan 1999; Aisenbrey 2000).

\section{Optimal matching: determining the difference between sequences}

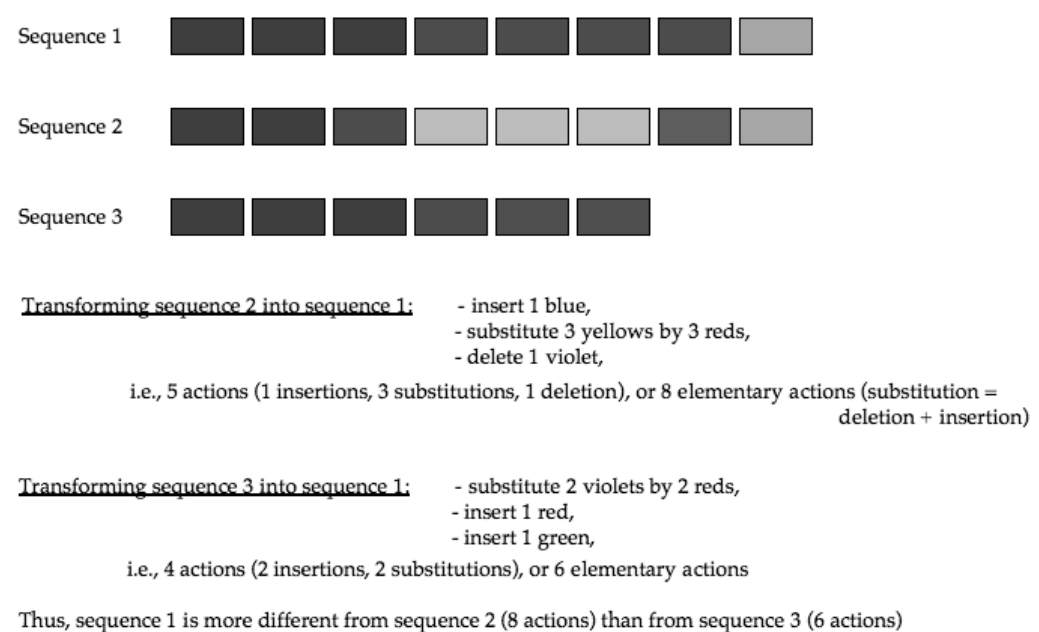

This method originated in biology where it is used for genome sequencing (e.g., Delcher et al. 1999). It allows to compare sequences of states that may have variable lengths or durations ${ }^{17}$ as to their degree of resemblance; it imposes little restrictions on the number of states or periods. The figure illustrates how individual sequences are compared pairwise by determining for each pair the minimal number and type of operations needed to transform one sequence into the other, the three possible operations being insertion of a supplementary element or state, deletion of an element, or substitution of one kind of element by another. ${ }^{18}$ Each of these operations can be "taxed" or weighted by a specific "cost" expressed in fractions of 1; the sum of these costs for the comparison of sequences measures the difference or distance between them. The costs of the three operations are set by the analyst for each analysis. ${ }^{19}$ The resulting distance matrix can then be cluster-analysed in order to identify trajectory types.

17 Obviously, the applicability of the method is not limited to temporal sequences. 18 We used the software TDA developed by Götz Rohwer (Rohwer \& Pötter 1999).

19 In principle, there are three options for cost setting: a) set substitution costs to 1 and INDEL to 0.5 (because substitution corresponds logically - if not semantically - to the combination of deletion plus insertion), b) use differentiated costs according to a theoretical 
Appendix table A1: Empirical description of male trajectory types (\% per type)

\begin{tabular}{lrcccc}
\hline \multirow{2}{*}{ Descriptors (\%) } & \multicolumn{2}{c}{ Trajectory types } & \multicolumn{2}{c}{ Cramer's } \\
\cline { 2 - 4 } & $\begin{array}{c}\text { Slow } \\
\text { career }\end{array}$ & $\begin{array}{c}\text { High } \\
\text { career }\end{array}$ & $\begin{array}{c}\text { Nonmobile } \\
\text { workers }\end{array}$ & $\begin{array}{c}\text { Middle } \\
\text { managmt }\end{array}$ & V \\
\hline Father higher occupation & 5.0 & 8.8 & 1.9 & 10.7 & $0.146^{*}$ \\
Father self-employed & 25.2 & 44.1 & 33.1 & 24.5 & $0.158^{* *}$ \\
Mother employed & 38.5 & 40.3 & 38.1 & 68.9 & 0.042 \\
Upward educ. mobility & 56.1 & 54.1 & 51.4 & 32.9 & $0.129^{*}$ \\
Higher occupation trained & 11.1 & 21.1 & 6.2 & 50.5 & $0.278^{* *}$ \\
Higher occupation actual & 22.4 & 31.2 & 7.3 & 72.2 & $0.361^{* *}$ \\
Self-employed actual & 8.8 & 22.6 & 3.3 & 1.0 & $0.575^{* *}$ \\
income $>$ 8.000 SFr. & 25.6 & 43.2 & 6.5 & 36.5 & $0.292^{* *}$ \\
Part-time & 6.2 & 11.3 & 6.9 & 12.6 & .080 \\
Not employed & 21.7 & 21.0 & 16.4 & 16.8 & 0.062 \\
Age $>$ 50 & 41.0 & 49.2 & 37.6 & 43.7 & 0.086 \\
\hline $\mathrm{N}$ & 161 & 124 & 189 & 119 & \\
\hline
\end{tabular}

Note: In order to simplify the table, descriptors are shown as dichotomies, each line giving the proportion of high values for a descriptor variable. We cut income at $8.000 \mathrm{SFr}$. for men and 6.000 SFr. for women in order to avoid extreme distributions because so many women work less than full-time and moreover in little-paid occupations. $\mathrm{N}$ varies somewhat owing to missing values, we give the $\mathrm{N}$ of each trajectory type.

Appendix table A2: Empirical description of female trajectory types (\% per type)

\begin{tabular}{lcccrrr}
\hline \multirow{2}{*}{ Descriptors (\%) } & \multicolumn{3}{c}{ Trajectory types } & \multicolumn{3}{c}{ Cramer's V } \\
\cline { 2 - 6 } & Slow career & High career & $\begin{array}{c}\text { Nonmobile } \\
\text { workers }\end{array}$ & Return & House-wives \\
\hline Father higher occupation & 20.0 & 17.6 & 8.3 & 4.6 & 6.7 & $0.174^{* *}$ \\
Father self-employed & 32.0 & 44.1 & 27.1 & 36.1 & 32.0 & 0.098 \\
Mother employed & 45.9 & 53.8 & 38.8 & 47.7 & 42.5 & 0.072 \\
Upward educ. mobility & 43.1 & 55.3 & 47.8 & 32.0 & 41.8 & $0.135^{*}$ \\
Higher occupation trained & 13.5 & 20.0 & 1.9 & 1.7 & 5.4 & $0.258^{* *}$ \\
Higher occupation actual & 15.2 & 44.8 & 1.6 & 1.5 & 11.4 & $0.442^{* *}$ \\
Self-employed actual & 28.3 & 27.6 & 4.8 & 0.0 & 11.4 & $0.346^{* *}$ \\
Income > 6.000 SFr. & 10.3 & 23.7 & 2.5 & 0.8 & 1.7 & $0.298^{* *}$ \\
Part-time & 55.7 & 51.3 & 64.8 & 51.9 & 23.6 & $0.328^{* *}$ \\
Not employed & 24.6 & 25.6 & 23.6 & 45.0 & 73.6 & $0.428^{* *}$ \\
Age > 50 & 16.4 & 28.2 & 32.1 & 43.4 & 41.4 & $0.176^{* *}$ \\
\hline $\mathrm{N}$ & 61 & 39 & 165 & 129 & 174 & \\
\hline
\end{tabular}

Note: In order to simplify the table, descriptors are shown as dichotomies, each line giving the proportion of high values for a descriptor variable. $\mathrm{N}$ varies somewhat owing to missing values, we give the $\mathrm{N}$ of each trajectory type.

judgement of the "difficulty" or "heaviness" of various substitutions or, in our case, transitions (higher costs for transitions that appear to be more challenging, i.e., higher cost for quitting employment than for reducing it), and c) differentiate costs according to (inversed) empirically determined relative frequencies of transitions (considering more frequent transitions to be less "costly" than less frequent ones). Experience shows that the basic algorithm is relatively robust with respect to costs, cost matrices have to be very different in order to generate clearly different results. In the present analysis, we have opted for the first possibility. 